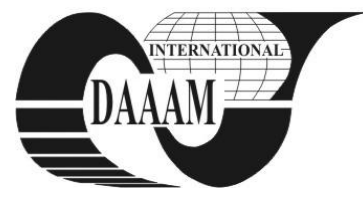

Annals of DAAAM for 2011 \& Proceedings of the 22nd International DAAAM Symposium, Volume 22, No. 1, ISSN 1726-9679 ISBN 978-3-901509-83-4, Editor B. Katalinic, Published by DAAAM International, Vienna, Austria, EU, 2011 Make Harmony between Technology and Nature, and Your Mind will Fly Free as a Bird

Annals \& Proceedings of DAAAM International 2011

\title{
STRENGTHENING OF THE ROMANIAN FINANCING CAPACITY IN CASE OF NATURAL DISASTERS
}

\author{
ZELINSCHI, G[abriel] A[rthur]
}

\begin{abstract}
Romania is highly exposed to natural disasters. Although the current system for natural disaster risk financing is being modernized, its capacity to cover all losses caused by extreme natural events is limited and the Government's residual fiscal exposure remains high. A better legal and institutional framework for natural disaster risk financing is required, together with ex-ante arrangements to access alternative modern financing sources as well as a Romanian National Reserve Fund. In addition, public buildings and public infrastructure should be incorporated in the existing compulsory insurance system. This would reduce the exposure of the Government to natural disasters losses.
\end{abstract}

Key words: disaster, insurance, residual risk, Romania

\section{INTRODUCTION}

Amongst all of the countries in Europe, Romania is one of the most exposed to natural disasters, especially floods, extreme temperatures, storms, earthquakes, landslides and drought. During the last 40 years 77 catastrophic events were recorded in Romania, at an average rate of 1.9 natural disasters annually (http://www.emdat.be).

Not all these natural disasters caused economic losses. Losses totalizing USD 6,086.6 million recorded during the period 1970-2010, as presented into the Table 1, were due only to floods, earthquakes and drought.

\begin{tabular}{|l|c|r|r|r|}
\hline \multirow{2}{*}{$\begin{array}{c}\text { Disaster } \\
\text { type }\end{array}$} & \multicolumn{2}{c|}{ Events } & \multicolumn{2}{c|}{ Damages } \\
\cline { 2 - 5 } & No. & \multicolumn{1}{c|}{$\%$} & $\begin{array}{c}\text { million } \\
\text { USD }\end{array}$ & \multicolumn{1}{c|}{$\%$} \\
\hline Floods & 41 & 53.3 & $3,587.6$ & 58.9 \\
\hline Earthquake & 4 & 5.2 & $2,000.0$ & 32.9 \\
\hline Drought & 2 & 2.6 & 500.0 & 8.2 \\
\hline Epidemic & 3 & 3.8 & 0.0 & 0.00 \\
\hline Extreme temperature & 17 & 22.1 & 0.0 & 0.00 \\
\hline Mass movement wet & 1 & 1.3 & 0.0 & 0.00 \\
\hline Storm & 9 & 11.7 & 0.0 & 0.00 \\
\hline Total & 77 & 100.0 & $6,086.6$ & 100.0 \\
\hline
\end{tabular}

Tab. 1. Natural disasters and economic damages in Romania during 1970-2010

Of the total recorded economic losses, floods caused the most losses with $58.9 \%$, followed by the greatest earthquake registered in Romania in 1977 with $32.9 \%$ and the drought of 2000 with $8.2 \%$.

The first conclusion from these statistics is that the priority in reducing economic losses caused by natural disasters should be prevention and mitigation measures against floods, earthquakes and drought. However, regardless of such measures, there is residual unmanaged risk. Since this risk cannot be removed, response and recovery capabilities have to be maintained. The losses caused by the residual risk may cause gaps in financing and, in order to avoid macroeconomic imbalances, these gaps must be financed.

\section{THE ADEQUACY OF CURRENT SYSTEM OF FINANCING NATURAL DISASTER RISK IN ROMANIA}

The system of financing natural disaster losses in Romania is currently being modernized. This involves a transition from an old ex-post approach, based on the risk retained almost entirely by the government, together with aid from the international Community, to a modern ex-ante approach, using instruments for catastrophe risk transfer.

However, due to the low penetration of catastrophe insurance in the Romanian non-life insurance market, public financial resources and aid from the international Community are still required to cover losses from extreme natural events. Supplementing these resources are household savings, donations from private business sector as well as other sources legally constituted.

Public financial resources from the state and local budgets, in the form of contingency funds, are intended to limit and to deal with the effects of known and regular natural disasters expected during each current financial year. The great disadvantage of this source of funding is that these resources are insufficient to meet the high economic losses caused by extreme natural events with a of recurrence period of tens or hundreds of years. For example, the earthquake that affected Romania in 1977 caused extensive damages which were 547 times greater than the allocated budgetary resources (Gurenko \& Zakout, 2008). Moreover, in case of public financial resources, their allocation may well be based on bureaucratic or political criteria, leading to less effective use of them (Mahul \& Gurenko, 2006).

Regarding external aid, the EU Solidarity Fund provides financial support from the international Community for Romania after natural disasters. The main disadvantage of this finance is that the volume of resources made available by the European Commission is not sufficient to cover the economic losses suffered. For example, in 2009, following the severe flooding the previous year, Romania received only $2.5 \%$ of the cost of damages suffered. Also, according with the Regulation (EC) 2012/2002 which establishes the Solidarity Fund of the European Union, the Fund's resources are intended to cover solely losses suffered by the public sector. The granting of this financial support is not conditional on affected states taking proactive measures to mitigate natural disaster, and it has mostly a humanitarian purpose (Linneroouth-Bayer et al., 2007).

In the Romanian non-life insurance market, both voluntary insurance against fire and other natural perils and compulsory insurance of residential property against earthquake, landslide and flooding have low levels of penetration (http://www.csaisc.ro). The trends in coverage of damages caused to property by natural disasters through voluntary insurance against fire and other natural perils in Romania between 2004 and 2009 are described in Table 2. 


\begin{tabular}{|c|c|c|c|c|}
\hline Year & $\begin{array}{c}\text { Gross } \\
\text { written } \\
\text { premiums } \\
\text { (mil. LEI) }\end{array}$ & $\begin{array}{c}\text { Weight } \\
\text { in total } \\
\text { non-life } \\
\text { insurances } \\
(\%)\end{array}$ & $\begin{array}{c}\text { Insurance } \\
\text { penetration } \\
\text { in the GDP } \\
(\%)\end{array}$ & $\begin{array}{c}\text { Insurance } \\
\text { density } \\
\text { (LEI/ } \\
\text { inhabitant) }\end{array}$ \\
\hline 2004 & 371.7 & 13.8 & 0.15 & 17.15 \\
\hline 2005 & 470.5 & 13.9 & 0.16 & 21.76 \\
\hline 2006 & 534.1 & 11.6 & 0.15 & 24.74 \\
\hline 2007 & 648.3 & 11.3 & 0.16 & 30.10 \\
\hline 2008 & 849.7 & 12.0 & 0.17 & 39.51 \\
\hline 2009 & 934.7 & 12.9 & 0.19 & 43.54 \\
\hline
\end{tabular}

Tab. 2. Romanian voluntary insurance against fire and other natural perils: market ratios

With respect to compulsory insurance, this is a new element in the Romanian non-life insurance market, and it was enacted in 2008. Although it entered into force in the mid of 2010, on the $15^{\text {th }}$ of July 2011, the Pool of Insurance against Natural Disasters in Romania (PAID) signed only 723,735 policies from a total of 8.385 million dwellings, resulting in a penetration rate of $8.63 \%$.

In light of the above mentioned issues, it may be concluded that although the current system on natural disaster risk financing in Romania is being modernized, it still lacks the capacity to cover all potential losses caused by an extreme natural event. Because of this the Government's residual fiscal exposure to a major natural catastrophe remains high and appropriate measures are needed to provide more financing capacity.

\section{MEASURES TO IMPROVE FINANCING CAPACITY IN THE EVENT OF NATURAL DISASTER LOSSES}

The first and most important measure needed is to improve the existing legal and institutional framework for natural disaster risk financing. This objective can be achieved by developing and implementing a national strategy for natural disaster risk financing, relevant to Romanian conditions, with a sound legal basis, and which would deal with the provision, distribution and use of the financial resources. The main goal of financing strategy should be to improve efficiency, effectiveness and to reduce costs. This legal framework should specify the conditions for access to funding and should use the latest alternative financing sources to cover all losses caused by natural disasters.

The next measure necessary is to identify and to access alternative modern financing sources for an ex-ante approach so as to complement the existing resources, in order to reduce the financing gap that may arise after an extreme natural event. Possibilities include specialty products from the IBRD for financing catastrophe risk: the Deferred Drawdown Option for Catastrophe Risk - Cat DDO and catastrophe bonds - Cat Bond (http://treasury.worldbank.org).

Since after an earthquake the national public budget is the only source available for financing direct economic losses suffered by public buildings, their coverage should be included in the existing compulsory insurance system. Another option is parametric insurance, which is more advantageous because losses are assessed on a predefined formula, and payments, are made promptly after a disaster occurs (Cummins \& Mahul, 2009). At the same time, this kind of insurance has the disadvantage of basis risk, since insurance recoveries may differ considerably from actual losses. To deal with this, the Government should have at his disposal the necessary resources to cover basis risk.

For financing losses suffered by other property, especially public infrastructure elements of the state and local authorities, another important measure would be the establishment of a
Romanian National Reserve Fund for natural disasters. These resources may also be used to partially offset the losses of the private business sector or households that arise from a natural event of high intensity. When insurers' and reinsurers' resources are insufficient, the Government assumes the role of the insurer of last resort.

In order to reduce the residual risk, another measure that should be implemented is the granting of tax incentives to households and private business sector to encourage natural disaster loss mitigation activities.

Finally, by conducting a public information campaign for raising public awareness of the need for insurance to protect property against losses from natural disasters, it indirectly contributes to the strengthening of Government's financing capacity by increasing the penetration of voluntary insurance against fire and other natural perils, as well as increasing the penetration of the compulsory insurance of residential property against earthquake, landslide and flooding.

\section{CONCLUSION}

So far the reform of the financing of risk of natural disasters in Romania has not produced the expected results. This is due to the fact that it is carried out outside of a financing strategy and also because of the Government's limited ability to mobilize adequate resources to meet to potential natural disaster losses. Implementation of the above mentioned measures is an imperative in order to reduce the Romanian Government's residual fiscal exposure to natural disaster losses.

This important objective can be only be realized at national level through a concerted effort involving disaster risk management, the insurance industry and capital markets, as well as, other Governmental and Non-Governmental Organizations.

\section{REFERENCES}

Cummins, J.D. \& Mahul, O. (2009). Catastrophe risk financing in developing countries - principle for public intervention, The World Bank, ISBN: 978-0-8213-7736-9, Washington DC

Gurenko, E. \& Zakout, W. (2008). Mitigating the Adverse Financial Effects of Natural Hazards on the Economies of South Eastern Europe, A Study of Disaster Risk Financing Options, South Eastern Europe Disaster Risk Mitigation and Adaptation Programme, Available from: http://www.unisdr.org/preventionweb/files/1742_SEEDRFi nancing.pdf Accessed: 2011-02-20

Linnerooth-Bayer, J.; Amendola, A.; Okada, N. \& Shi, P. (2007). Disaster risk management: pro-active financing to reduce vulnerability, Environmental Hazards 7 (2007) 1-6, Available

from: http://www.uottawaglobe.ca/files/risk\%20management.pdf Accessed: 2011-03-15

Mahul, O. \& Gurenko, E. (2006). The Macrofinancing of Natural Hazards in Developing Countries, WPS4075, Available from: http://ideas.repec.org/p/wbk/wbrwps/4075.html Accessed: 2011-02-21

*** (2011) http://www.emdat.be - EM-DAT: The International Disaster Database - Centre for Research on the Epidemiology of Disasters - CRED, Université Catholique de Louvain - Brussels - Belgium, Accessed on: 2011-02-10

*** (2011) http://www.csa-isc.ro - The Romanian Insurance Supervisory Commission, Annual Reports, Accessed on: 2011-03-12

*** (2011) http://treasury.worldbank.org - The World Bank Treasury, Financing \& Risk Management, Catastrophe Risk Financing, Accessed on: 2011-03-05 